\title{
THE DEATH KNELL FOR THE DEATH PENALTY AND THE SIGNIFICANCE OF GLOBAL REALISM TO ITS ABOLITION FROM GLOSSIP V. GROSS TO BRUMFIELD V. CAIN
}

\author{
LINDA A. MALONE*
}

\begin{abstract}
INTRODUCTION
The Supreme Court's jurisprudence regarding the death penalty, whether or not cruel, has most certainly been unusual in the annals of criminal punishment. In just four years, the Court foreclosed this form of punishment in Furman v. Georgia and then reopened it as a possibility in Gregg v. Georgia. ${ }^{1}$ One year later, the Court categorically excluded the punishment for the rape of an adult. ${ }^{2}$ Five years later, the Court again precluded the punishment for any defendant convicted of felony-murder who did not participate or share in the homicidal act or intent. ${ }^{3}$ In 1986, in Ford v. Wainwright ${ }^{4}$ the Court would struggle with the Orwellian issue of whether and how competent a person must be to be executed. In 1989, in two cases decided on the same day, the Court
\end{abstract}

Copyright $(92016$ Linda A. Malone.

*Visiting Professor, Duke Law School; Marshall-Wythe Foundation Professor of Law, William and Mary Law School. The author gratefully acknowledges the research assistance of Melanie Lazor, Kathleen Zaratzian, Seth Peritz, Thomas Sandbrink, Darren Ziegler, and Kathy Burger, and the technical support of Derek Mathis. The article benefited from the input of Neal Katyal, Adam Liptak, Linda Greenhouse, Joseph Blocher, Jeffrey Kovar from the Office of the Legal Advisor in the U.S. State Department, the International Criminal Law Committee of the ABA, particularly Robert Weinberg and Rosa Lima, and the contributors to this issue. Additional input was provided by the participants in the 2016 annual meeting of the International Society for the Reform of Criminal Law.

1. Furman v. Georgia, 408 U.S. 238 (1972); Gregg v. Georgia, 428 U.S. 153 (1976).

2. Coker v. Georgia, 433 U.S. 584 (1977).

3. Enmund v. Florida, 458 U.S. 782 (1982).

4. 477 U.S. 399 (1986). 
refused to find that the "mentally retarded" or juveniles were categorically exempt from the death penalty in opinions that both embodied the "national consensus" 5 test for death penalty restrictions and questioned its exclusivity as the determinate measure of cruel and unusual punishment. ${ }^{6}$

In the decade that followed, the ground began to shift under the Court's jurisprudence in a number of ways. Coalitions opposed to the death penalty expanded to encompass international human rights advocates, dedicated as amicus curiae or pro bono counsel. This coalition highlighted in its advocacy the United States' growing isolation in its official acceptance of the punishment. ${ }^{7}$ The 2002 landmark case of Atkins v. Virginia invigorated categorical exclusions from the death penalty, recognizing that the "mentally retarded" could not be subject to the harshest form of punishment. ${ }^{8}$ Roper $v$. Simmons added juvenile offenders to the categorical exclusions. ${ }^{9}$ In 2008, rape of a child when the crime did not result and was not intended to result in the victim's death was also excluded. ${ }^{10}$ In the four years after Roper, the Court would protect juvenile offenders from life without parole, first for nonhomicidal offenses, ${ }^{11}$ then for any offense. ${ }^{12}$ The Montgomery $v$. Louisiana decision on January 25,2016 applied the prohibition on life without parole for juvenile offenders retroactively, releasing prisoners who had spent their entire "adult" lives behind bars. ${ }^{13}$

In addition, the Court found itself mired after Furman in what one commentator described as "an unparalleled level of constitutional micromanagement" as to how the death penalty can be imposed procedurally and when it can be imposed based on the nature of the offense and the status of the offender. ${ }^{14}$ In the October 2015 term alone, the Court granted certiorari in a consolidated trio of cases and an additional case raising such procedural issues. ${ }^{15}$

5. See infra notes 59-62, 69-76, and 127-151. Generally, the test measures what is cruel and unusual by how many states have banned or permitted a certain punishment.

6. Penry v. Lynaugh, 492 U.S. 302 (1989); Stanford v. Kentucky, 492 U.S. 361 (1989).

7. See infra notes $162-163$ and accompanying text.

8. 536 U.S. 304 (2002).

9. 543 U.S. $551(2005)$.

10. Kennedy v. Louisiana, 554 U.S. 407 (2008).

11. Graham v. Florida, 560 U.S. 48 (2010).

12. Miller v. Alabama, 132 S. Ct. 2455 (2012).

13. 136 S. Ct. 718 (2016).

14. Scott E. Sundby, The True Legacy of Atkins and Roper: the Unreliability Principle, Mentally Ill Defendants, and the Death Penalty's Unraveling, 23 WM. \& MARY BILL RTS. J. 487, 489 (2014).

15. See generally Jess Bravin, Supreme Court Docket Loaded with Death-Penalty Cases , 
Against this backdrop, the Court's 2015 decision in Glossip v. Gross seems a notable victory for the death penalty. ${ }^{16}$ In the almost inevitable 5-4 split, the Court refused to find that the specific method of execution, a three-drug protocol beginning with midazolam, constituted cruel and unusual punishment. ${ }^{17}$ The decision is at best a Pyrrhic victory for the death penalty, however, given the specificity of the method in question. More importantly, the majority opinion was largely eclipsed by Justice Breyer's dissent, joined by Justice Ginsburg, which called for total abolition of the death penalty. ${ }^{18}$ The conflict evidenced by the dissenting opinion in Glossip shows the need for a "global realism" recognizing that in the Supreme Court's jurisprudence, consideration of international legal norms and political realities is unavoidable. The method of execution itself necessarily resulted from foreign drug suppliers' refusal to continue supplying drugs for execution purposes, and Justice Breyer's dissent again brought to the forefront the United States' isolation in its acceptance of the death penalty. ${ }^{19}$

Glossip v. Gross, thus, may be the beginning of the end of the death penalty, due to factors compelling the Supreme Court to hold that the death penalty is a violation of the Eighth Amendment prohibition on cruel and unusual punishment. First, constitutional legal analysis has shifted steadily from the "national consensus" 20 analysis to proportionality and penological purposes served in Eighth Amendment cases. Second, mounting empirical evidence shows no national consensus in favor of the death penalty. Third, there is a renewed recognition that decisionmaking in capital cases is arbitrarily applied no matter what procedural

WALL STREET JOURNAL (October 4, 2015), http://www.wsj.com/articles/supreme-court-docketloaded-with-death-penalty-cases-1443999113.

16. 135 S. Ct. 2726 (2015).

17. See id.

18. See id. at 2755 (Breyer, J., dissenting).

19. See infra notes 177-217 and accompanying text. As this article focuses on Breyer's dissent as a roadmap for challenging the death penalty in the Supreme Court, it does not address the issue of the exorbitant costs of pursuing the death penalty compared to the benefits which has been the focus of much commentary. See, e.g., Adam Gershowitz, An NTSB for Capital Punishment, 47 TEXAs TECH. L. REV. 151, 154 (2014) ("Certainly, as a matter of pure utility, the cost of capital punishment - arbitrariness, discrimination, and actual dollars spent - appears to be vastly greater than the benefits (primarily questionable claims of deterrence) it tangibly provides to society."); see also id. at $153 \mathrm{n} .17$ (citing Corinna Barrett Lain, The Virtues of Thinking Small, 67 U. MIAMI L. REv. 397, 408-09 (2013) for explaining that cost was a factor in the decision of five states to repeal their death penalty statutes). See also Charles Blow, Eye-for-an-Eye Incivility, N.Y. TIMES, May 5, 2014, at A23 (quoting Professor Jeffrey A. Fagan that "[T]he price of obtaining convictions and executions ranges from $\$ 1.5$ million to $\$ 5$ million per case (in current dollars), compared to less than $\$ 1$ million for each killer sentenced to life without parole.").

20. See supra note 5 and accompanying text. 
prerequisites the Court imposes. Lastly, the significance of international norms and practices in determining "evolving standards of decency" under the Eighth Amendment is finally recognized. This recognition of the beginning of the end is explicit in Justice Breyer's dissent and is also fundamental in evaluating Justice Kennedy's position if confronted with a facial challenge notwithstanding his joining the majority in Glossip v. Gross. ${ }^{21}$ As the quintessential swing vote of the nine Justice Court, Justice Kennedy's vote on the issue is inevitably a focus for the prospects of abolition of the death penalty. Given the current vacancy on the Court, this article will also address the potential outcome from a nine Justice Court with a newly appointed Justice. ${ }^{22}$

\section{An EMERging Abolition COALITION ON THE COURT?}

It is routine to predict the future direction of Supreme Court opinions in the current Supreme Court by the so-called swing vote of Justice Kennedy, even though the Court appears to have had more cohesive decisions under Chief Justice Roberts than in years past. ${ }^{23}$ That said, Justice Kennedy's voting pattern since his appointment in 1988 in death penalty cases is illuminating as to his possible accord with Justice Breyer's call for abolition of the death penalty as cruel and unusual

21. See 135 S. Ct. 2726 (2015).

22. As this article was going to press, President Obama nominated Merrick B. Garland, Chief Judge of the D.C. Circuit Court of Appeals, to fill Justice Scalia's seat, but many Republican Senators in Congress denied that he would receive a confirmation hearing before the election. Enmarie Huetteman, Mikayla Bouchard, Josh Keller, \& Larry Buchanan, Where Republican Senators Stand on the Supreme Court Nomination, N.Y. TIMES (March 23, 2016), http://www.nytimes.com/interactive/2016/03/21/us/politics/where-republican-senators-stand-on-the-supremecourt-nomination.html?_r=0. As one purpose of this article is to analyze the death penalty under the Eighth Amendment without resorting to political labels or such categorizations of the Justices, it will only be noted that Judge Garland was the initial prosecutor in the Timothy McVeigh death penalty case, and in his 1995 confirmation hearing for the D.C. Circuit when asked about the death penalty said it was "settled law":

Senator SPECTER. Do you favor, as a personal matter, capital punishment?

Mr. GARLAND. This is really a matter of settled law now. The Court has held that capital punishment is constitutional and lower courts are to follow that rule.

Senator SPECTER. Well, I shall now push you on a direct response to my question. You are prepared to apply the law which supports capital punishment as a constitutional punishment?

Mr. GARLAND. Yes. Mr. Chairman, I have been a prosecutor. As a prosecutor, I have recommended that the Government seek the death penalty. I don't see any way in which my views would be inconsistent with the law in this area.

Materials on file with author; see also Sarah Almukhtar, Why Obama Nominated Merrick Garland for the Supreme Court, N.Y. TIMES (March 16, 2016), http://www.nytimes.com/interactive/2016/03/16/us/politics/garland-supreme-court-nomination.html

23. Neal K. Katyal, Law vs. Politics on the Court, N.Y. Times, June 27, 2014, at A23. 
punishment. ${ }^{24}$ His authorship of all of the post-1989 opinions categorically limiting the death penalty may indicate even more significantly the evolved coalition of Justices willing to abolish the death penalty, as opposed to the seeming triumph of the pro-death penalty outcome in Glossip v. Gross. ${ }^{25}$

Before Justice Kennedy joined the Court, the Court found the implementation of the death penalty unconstitutional in 1972 in Furman ${ }^{26}$ reinstated it with qualifications in 1976 in Gregg, ${ }^{27}$ and then in 1977 prohibited its imposition for rape of an adult in Coker ${ }^{28}$ Justice Kennedy had barely served a year on the Court before confronting two cases in which categorical exclusions from the penalty were unsuccessfully sought, and he joined in that result in $1989 .{ }^{29}$ As the junior Justice at that time, his departure from the accepted "national consensus" analytical framework must have been striking, and just sixteen years later - a brief time by constitutional measure - both cases were overruled with Justice Kennedy's support. ${ }^{30}$

In Penry v. Lynaugh the Supreme Court granted certiorari to answer two questions: first, did Penry's death sentence violate the Eighth Amendment because the jury was unable to consider mitigating evidence in answering the special questions, and second, is it cruel and unusual punishment to execute a "mentally retarded" person of Penry's capabilities? $?^{31}$ The Court had previously determined in Teague v. Lane that relief that, if granted, would constitute a "new rule" cannot be announced or applied retroactively to a petitioner's case, barring two exceptions. ${ }^{32}$ Although Teague was not a capital case, the Court determined both the general concept that new rules should not be retroac-

24. See infra notes 69-176 and accompanying text.

25. See infra notes 77-94 and accompanying text.

26. 408 U.S. 238 (1972)

27. 428 U.S. 153 (1976)

28. See supra notes 1-2 and accompanying text.

29. See supra note 6 and accompanying text.

30. See supra notes 8-9 and accompanying text.

31. 492 U.S. 302, 313 (1989).

32. 489 U.S. 288,301 (1989). A "new rule" is one that imposes a new obligation on the government, one that was not dictated by precedent at the time of the initial trial's conclusion. Id. The two exceptions were if the new rule placed certain primary private acts or conduct beyond the power of criminal law to proscribe, or if the new rule corrects an inaccuracy at trial that implicated the fundamental fairness of the trial. $I d$. at 311-12. Neither exception applied to this aspect of Penry's case, but the first exception was expanded in Part IV-A regarding Penry's claim that the Eighth Amendment entirely barred the execution of the mentally retarded. Id. at 32930 . 
tive and the specific exceptions that would allow retroactive application to death penalty cases. ${ }^{33}$

Justice O'Connor, writing for the Court then, examined if Penry's request that his jury be required to consider any mitigating evidence before assigning the death penalty was a new rule under Teague..$^{34}$ If so, the mitigating evidence could not be applied retroactively to Penry's case on collateral appeal. ${ }^{35}$ The Court in 2016 would address the issue of whether the exclusion of a life sentence without parole for juveniles in Miller should be applied retroactively under Teague. ${ }^{36}$ The Court held that Penry had a constitutional guarantee that his jury must consider any such mitigating evidence before passing a death sentence. ${ }^{37}$ Therefore, Penry's request was not for a new rule, but for Texas to follow its extant constitutional obligation to ensure that the jury would consider all relevant mitigating evidence Penry may present during the sentencing in a capital case. ${ }^{38}$

The Court then turned to Penry's first issue: whether the special questions presented to the jury during the penalty phase of his trial violated his constitutional rights by leaving the jury unable to properly consider mitigating evidence when contemplating the death penalty. ${ }^{39}$ The Court reiterated that Texas's procedure is only constitutional if the special questions allow for consideration of mitigating factors, ${ }^{40}$ and that a sentencing party not only may consider mitigating evidence but must consider it in capital cases. ${ }^{41}$ The Court found the underlying legal reasoning for these rules was that "punishment should be directly related to the personal culpability of the criminal defendant," ${ }^{42}$ and that

33. Id. at $313-14$.

34. Id. at $314-19$.

35. Id. at 314-19.

36. 136 S. Ct. 718 (2016) (holding that Miller v. Alabama announced a new substantive constitutional rule that was retroactive on state collateral review).

37. Penry, 489 U.S. at 328. See Eddings v. Oklahoma, 455 U.S. 104 (1982) (holding that the sentencing party must consider all relevant mitigating evidence presented by the defense as a matter of law). See also Jurek v. Texas, 428 U.S. 262 (1976) (upholding Texas's death penalty statute under the Eighth Amendment, but guaranteeing that the special issues presented to the jury be interpreted broadly enough to allow the sentencing party to consider all relevant mitigating evidence presented by the defense); Lockett v. Ohio, 438 U.S. 586 (1978) (holding that the defendant's death sentence survived Jurek because the Texas Court of Criminal Appeals interpreted the second special question constitutionally broadly, despite the question's facial narrowness).

38. Penry, 492 U.S. at 318-19.

39. Id. at 319-28.

40. Jurek, 428 U.S. at 272.

41. Eddings, 455 U.S. at 114-17.

42. Penry, 492 U.S. at 319. 
"defendants who commit criminal acts that are attributable to a disadvantaged background, or to emotional and mental problems, may be less culpable than defendants who have no excuse." ${ }^{43}$

Although the Court agreed with the state that Penry's mental retardation was relevant to the first special question-whether Penry had acted, or was capable of acting, deliberately-it also had great relevance to Penry's moral culpability for his crime, which is beyond the scope of the question..$^{44}$ The state argued that, despite the narrowness of the special questions, the jurors were still free to vote their conscience if they believed that there were mitigating factors which would lead them to be merciful to Penry, and in fact, the defense counsel urged the jury to do so in the interest of justice. ${ }^{45}$ Nevertheless, because the prosecution explicitly told the jury in rebuttal that the jurors had taken an oath to follow the law, and must follow their instructions as given, the Court found that "a reasonable juror could well have believed that there was no vehicle for expressing the view that Penry did not deserve to be sentenced to death based upon his mitigating evidence." ${ }^{\prime 6}$ Therefore, the Court concluded that Penry's case should be remanded for resentencing to avoid the risk that the death penalty would be imposed in spite of factors that may call for something less severe. ${ }^{47}$

The Court finally turned to Penry's second issue on appeal: whether the Eighth Amendment barred the execution of a "mentally retarded" defendant. ${ }^{48}$ Because there was no established rule that the Eighth Amendment prevented the execution of the "mentally retarded" at the time of Penry's conviction, the Court held that this would constitute a "new rule" under Teague. ${ }^{49}$ However, the first exception to Teague is that a new rule may be retroactive on collateral appeal if it placed "primary conduct" of the petitioner beyond the scope of criminal law. ${ }^{50}$ In the Court's view, "a new rule placing a certain class of individuals beyond the State's power to punish by death is analogous to a new rule

43. Id. (quoting California v. Brown, 479 U.S. 538, 545 (1987)).

44. Id. at 323. The court also considered Penry's retardation with respect to the other special questions, but found that it had no relevance to the third question, as to whether Penry's acts were unreasonable, and could actually be an aggravating factor for the second question, as Penry's inability to learn from his mistakes could make it more likely a jury would see Penry as a future violent threat to society. $I d$. at 323-25.

45. Id. at 325 .

46. Id. at $325-26$.

47. Id. at 328 .

48. Id. at 330-35.

49. Id. at 329 .

50. Teague v. Lane, 489 U.S. 288, 307 (1989). 
placing certain conduct beyond the State's power to punish at all.".51 Therefore, the Court expanded this exception to Teague's general prohibition against retroactivity to encompass "rules prohibiting a certain category of punishment for a class of defendants because of their status or offense." 52 The Court reiterated that the Eighth Amendment prohibited at a minimum punishments considered cruel and unusual in the English common law at the time the Amendment was adopted, but was not limited to practices condemned by the common law in 1789.53

Generally, the common law prohibited punishment of "idiots" and "lunatics" for crimes committed due to their disabilities..$^{54}$ This prohibition was the precursor to the modern insanity defense. ${ }^{55}$ "Idiot" had no standardized definition at common law, but "was generally used to describe persons who had a total lack of reason or understanding, or an inability to distinguish between good and evil." 56 The Court found some similarities between the common law definition of an "idiot" who could not be punished for his crimes, and the modern view of mental retardation; however, the Court saw the common law definition as applying to people "wholly lacking the capacity to appreciate the wrongfulness of their actions," which is more analogous to someone with "severe" or "profound" retardation rather than someone of Penry's capacity ${ }^{57}$ Penry's insanity defense was rejected and he was found competent to stand trial.

In addition, unlike what the Court found with regard to the insane, for whom there was a national consensus against execution, ${ }^{58}$ only two states had statutes against executing the mentally retarded for capital crimes, one of which had yet to go into effect. ${ }^{59}$ Even taking into account the fourteen states prohibiting capital punishment altogether, the Court found no national consensus against executing the mentally retarded that would justify expanding the common law definition of cruel

51. Penry, 492 U.S. at 330.

52. Id.

53. Id. (citing Ford v. Wainwright, 477 U.S. 399 (1986)).

54. Penry, 492 U.S. at 331-32.

55. Penry, 492 U.S. at 331-32.

56. Id.

57. Id. at 332-33. The Court's reasoning here implies that the Eighth Amendment would categorically prohibit the execution of a defendant with an IQ of 40 or lower, as "severely" retarded and thus similar enough to the common law definition of idiocy. Id. at 318-19.

58. See Ford, 477 U.S. at 399.

59. Penry, 492 U.S. at 333-34. 
and unusual punishment. ${ }^{60}$ Although there was polling indicating widespread public opposition to executing the "mentally retarded", this opposition had not yet made its way into legislation, which the Court considered "an objective indicator of contemporary values upon which [it could] rely." 61

Justice O'Connor considered the retribution theory of criminal punishment and its basis in proportion to the culpability of the offender with regards to mental retardation, which "has long been regarded as a factor that may diminish an individual's culpability for a criminal act." However, O'Connor found she could not "conclude that all mentally retarded people of Penry's ability - by virtue of their mental retardation alone, and apart from any individualized consideration of their personal responsibility -inevitably lack the ... capacity to act with the degree of culpability associated with the death penalty," and that mental retardation was better viewed as a mitigating factor in capital sentencing than an absolute bar. ${ }^{63}$

The Fifth Circuit's judgment was affirmed in part and reversed in part, and remanded to the trial court for sentencing procedures that would allow Penry to present evidence of his mental retardation and history of abuse as mitigating factors against sentencing him to death. ${ }^{64}$ However, the Court found no absolute Eighth Amendment protection against the execution of the mentally retarded. ${ }^{65}$ Instead, the Court viewed that common law ban as applicable to only those considered "severely" or "profoundly" retarded, with an IQ of 40 or below. ${ }^{66}$ On this second issue, Justices Brennan and Marshall dissented, with Brennan noting that the punishment was unconstitutional under both a proportionality analysis weighing the gravity of the offense with the harshness of the penalty, and as failing to further the penal goals of deterrence or retribution. ${ }^{67}$

It is impossible to view the Court's references to "idiots," "lunatics," and the "mentally retarded," however historically justified, without recognizing that public and scientific understanding of intellectual disabil-
60. Id. at 334 .
61. $I d$. at 335 .
62. Id. at 335-37.
63. Id. at 338 .
64. Id. at 340 .
65. Id. at $339-40$.
66. Id. at 339-40.
67. Id. at 343-49 (Brennan, J., dissenting). 
ities and mental illness have changed dramatically as part of the national consensus (although it would be 2014 before Justice Kennedy would substitute "intellectually disabled" for the earlier label of "mental retardation"). ${ }^{68}$ In a 1989 case decided the same day as Penry, Justice Kennedy joined Justice Scalia's opinion in Stanford $v$. Kentucky that the death penalty was not cruel and unusual punishment for juveniles over 15 but under 18 at the time of the crime. ${ }^{69}$ Although Justice Scalia would have started and ended the analysis with what punishment was allowed by the national consensus of states ${ }^{70}$ Justice O'Connor separately concurred in the lack of consensus and ultimately the judgment, concluding that the Court should have conducted a proportionality analysis before reaching its conclusion. ${ }^{71}$

Justice Brennan, joined in his dissent by Justices Blackmun, Marshall, and Stevens, took note of "what Justice Scalia calls, with evident but misplaced disdain, 'ethicoscientific' evidence" to determine whether the punishment was disproportionate or served no legitimate penal goal. ${ }^{72}$ The dissent goes on to cite as relevant that "within the world community, the imposition of the death penalty for juvenile crimes appears to be overwhelmingly disapproved." 73 Stanford v. Kentucky, ${ }^{74}$ along with the 1988 certiorari application in High v. Zant, ${ }^{75}$ would mark the start of a committed campaign of international human rights advocates to bring international and comparative law norms to the attention of the Court in the context of the death penalty.

\footnotetext{
68. Hall v. Florida, 134 S. Ct. 1986, 1989 (2014).

69. See 492 U.S. 361 (1989).

70. See 492 U.S. 361, 364-380 (Scalia, J.) (1989).

71. Id. at 381 (O'Connor, J., concurring).

72. Id. at 383 (Brennan, J., dissenting).

73. Id. at 390. "Article 6(5) of the International Covenant on Civil and Political Rights, Annex to G.A.Res. 2200, 21 U.N.GAOR Res. Supp. (No. 16) 53, U.N.Doc. A/6316 (1966) (signed but not ratified by the United States), reprinted in 6 INT'L LEGAL MATERIAL 368, 370 (1967); Article 4(5) of the American Convention on Human Rights, O.A.S. Official Records, OEA/Ser. K/XVI/1.1, Doc. 65, Rev. 1, Corr. 2 (1970) (same), reprinted in 9 INT'L LEGAl MATERIAL 673, 676 (1970); Article 68 of the Geneva Convention Relative to the Protection of Civilian Persons in Time of War, August 12, 1949, 6 U.S.T. 3516, T.I.A.S. No. 3365 (ratified by the United States). See also Resolutions and Decisions of the United Nations Economic and Social Council, Res.1984/50, U.N.ESCOR Supp. (No. 1), p. 33, U.N.Doc. E/1984/84 (1984) (adopting "safeguards guaranteeing protection of the rights of those facing the death penalty," including the safeguard that "[p]ersons below 18 years of age at the time of the commission of the crime shall not be sentenced to death"), endorsed by the United Nations General Assembly, U.N.GAOR Res. 39/118, U.N.Doc. A/39/51, p. 211, III 2, 5 (1985), and adopted by the Seventh United Nations Congress on the Prevention of Crime and the Treatment of Offenders, p. 83, U.N.Doc. A/Conf. 121/22, U.N. Sales No. E.86.IV.1 (1986)." Id. at 390 n.10.

74. See 492 U.S. 361 (1989).

75. On file with the journal.
} 
In 2002, Justice Stevens, as senior Justice in the majority, would write the opinion in Atkins v. Virginia overruling Penry and prohibiting imposition of the death penalty on the mentally disabled. ${ }^{76}$ Three years later, Justice Stevens would assign Roper v. Simmons ${ }^{77}$ to Justice Kennedy, for the opinion which would overrule Stanford v. Kentucky ${ }^{78}$ and prohibit the death penalty for juveniles over the age of 15 but under 18 when the capital crime was committed..$^{79}$ In that opinion, Justice Kennedy would write at the outset that the Atkins decision "returned to the rule, established in decisions predating Stanford, that "the Constitution contemplates that in the end our own judgment will be brought to bear on the question of the acceptability of the death penalty under the Eighth Amendment." " 80 Ironically, the petitioner in Roper argued that there was no national consensus against the death penalty for juveniles based in part on the United States' ratification of the International Covenant on Civil and Political Rights with a reservation to preserve capital punishment for juveniles. ${ }^{81}$ The opinion found that to be only "faint support," particularly when considered with subsequent Congressional legislation abolishing the punishment for federal crimes committed by juveniles. ${ }^{82}$

In addition to finding a state consensus against the death penalty's imposition, the Roper opinion predominantly focused on the "unreliability" of juveniles being classified among the worst offenders, and concomitantly the failure of the death penalty to serve any penological justification for juvenile offenders. ${ }^{83}$ Most significantly from the perspective of global realism, Part IV of the opinion focuses on the "reality" of

76. See 536 U.S. 304 (2002). As often seems to be the case, even those decisions which garner the most public attention when decided, disappear from the public domain of discussion with respect to their individual outcomes. What happens after many of the Supreme Court death penalty decisions also indicates that the death penalty system is arbitrary and fatally flawed. Atkins is one such example, which highlights the inability of juries to give the objective, individual consideration to mitigating circumstances required by the Court's decisions. On remand, the jury would again find that Atkins was intellectually disabled. Atkins was spared the death penalty due to the judge's determination that the evidence that Atkins was the triggerman was obtained by prosecutorial misconduct. See Mark E. Olive, The Daryl Atkins Story, 23 WM. \& MARY BILL RTS. J. 363 (2014). Twelve years after Atkins, the Court would decide in Hall v. Florida, 134 S. Ct. 1986 (2014) that an IQ cutoff of 70 for intellectual disability precluded the individual assessment constitutionally required. Other examples are included in the notes that follow for the principal cases.

77. 543 U.S. 551 (2005).

78. 492 U.S. 361 (1989).

79. 543 U.S. 551 (2005).

80. Id. at 563 .

81. Id. at 567 .

82. Id.

83. See id. 
the United States being the only country that gave "official sanction" to the juvenile death penalty. ${ }^{84}$ Only the United States and Somalia had not ratified the UN Convention on the Rights of the Child which prohibits the penalty, and Somalia had not executed a juvenile offender since before $1990 .{ }^{85}$ From this Justice Kennedy concludes:

It is proper that we acknowledge the overwhelming weight of international opinion against the juvenile death penalty, resting in large part on the understanding that the instability and emotional imbalance of young people may often be a factor in the crime. See Brief for Human Rights Committee of the Bar of England and Wales et al. as Amici Curiae 10-11. The opinion of the world community, while not controlling our outcome, does provide respected and significant confirmation for our own conclusions. It does not lessen our fidelity to the Constitution or our pride in its origins to acknowledge that the express affirmation of certain fundamental rights by other nations and peoples simply underscores the centrality of those same rights within our own heritage of freedom. ${ }^{86}$

Justice Kennedy would go on to write the majority opinions in Panetti v. Quarterman,${ }^{87}$ Kennedy v. Louisiana ${ }^{88}$ Graham v. Florida,${ }^{89}$ Hall v. Florida ${ }^{90}$ and Montgomery v. Louisiana. ${ }^{91}$ Justice Kennedy would also be in the majority in Miller v. Alabama, which held there should be no life without parole sentence for juveniles ${ }^{92}$ and Brumfield v. Cain, which required hearing prerequisites on intellectual disabilities, ${ }^{93}$ written by Justices Kagan and Sotomayor respectively. For both Miller and Brumfield, Justice Kennedy would have assigned the two junior Justices to those opinions as Senior Justice in the majority. ${ }^{94}$ In the five

84. Id. at 575 .

85. Id. at 576 .

86. $I d$. at 578 .

87. 551 U.S. 930 (2007) (holding that prisoner's documented delusions were constitutionally required to be considered in determining whether he was competent to be executed, as explained in Ford).

88. 554 U.S. 407 (2008) (holding that punishing a crime of child rape with the death penalty violates the Eighth Amendment).

89. 560 U.S. 48 (2010) (holding that the Eighth Amendment prohibits imposition of life without parole sentence on a juvenile offender who did not commit homicide).

90. 134 S. Ct. 1986 (2014) (holding that state rule violated the Eighth Amendment because it foreclosed further investigation of a capital defendant's intellectual disability if his IQ score was more than 70 and created unacceptable risk that persons with intellectual disability would be executed).

91. 136 S. Ct. 718 (2016) (holding that Miller v. Alabama announced a new substantive constitutional rule that was retroactive on state collateral review).

92. 132 S. Ct. 2455 (2012).

93. 135 S. Ct. 2269 (2015).

94. See Lawrence Baum, The Supreme Court 153 (3d ed. 1989). 
opinions authored by Justice Kennedy, several threads of normative analysis emerge consistently. These norms are best illustrated in Panetti, Hall, and most recently Montgomery v. Louisiana.

The Court as a procedural matter had to address Panetti's contention that Ford, ${ }^{95}$ along with the Eighth and Fourteenth Amendments, entitled him to certain procedures in his sentencing hearing unconstitutionally denied to him by the state of Texas. ${ }^{96}$ The Court agreed that after a defendant makes a "substantial showing of incompetency," Ford entitles him to "among other things, an adequate means by which to submit expert psychiatric evidence in response to the evidence that had been solicited by the state court." ${ }^{97}$

The Ford standard does not specify exact procedures for the state to follow, but requires a "fair hearing" on the issue of the petitioner's competency, one in which the petitioner has an opportunity to be heard and whose ultimate evaluation is based on more than the findings of psychiatrists appointed by the state. ${ }^{98}$ The Court found that for Panetti's case, the state was deficient in its procedures due to a lack of adequate recordkeeping, a failure to keep Panetti and his counsel informed throughout the proceedings, a failure to provide a competency hearing, and a failure to allow Panetti to submit any evidence in response to the court-appointed psychiatrists' evaluations. ${ }^{99}$

The Court did not rule on whether Ford requires specific procedures such as the opportunity for discovery or ability to cross-examine witnesses. ${ }^{100}$ Instead, the Court found that Texas's procedure regarding Panetti was so clearly deficient in other ways as to render further questions unnecessary. ${ }^{101}$ Citing to Ford, the Court held that it did not need to defer to the state court's finding of competency because Texas's procedure was inadequate for ascertaining the truth at trial. ${ }^{102}$

The Court then turned to Panetti's question as to whether the Eighth Amendment prohibited the execution of a prisoner whose mental illness deprived him of the capacity to understand he is being executed as a punishment for a crime. ${ }^{103}$ The Court looked to the record to

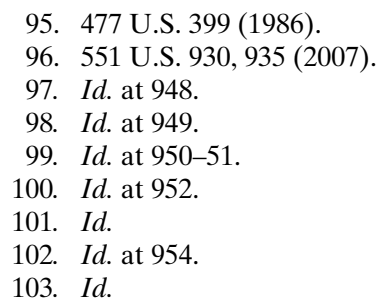


see what specific form Panetti's illness took to determine if he was unable to be executed. ${ }^{104}$

Four expert witnesses testified on Panetti's behalf during the District Court proceedings. ${ }^{105}$ They explained that Panetti suffered from delusions related to his execution, such that he had mentally recast himself as a warrior for God after his sentence, with the state attempting to execute him to stop him from preaching. ${ }^{106}$ The state argued that Panetti was still at times clear and lucid and could sufficiently understand the concept of his execution to be considered competent. ${ }^{107}$

The Court of Appeals ultimately found Panetti competent via a three-part test based on the Court's holding in Ford: ${ }^{108}$ first, that Panetti was aware he committed the murders; second, that Panetti was aware he would be executed; and third, that Panetti was aware that his crimes were the reason the state gave for his execution. ${ }^{109}$ The appeals court found that while Panetti's delusions may have caused him to disbelieve the state's reasons for executing him and to be unable to rationally understand them, his awareness of the state's reasoning was sufficient. ${ }^{110}$

The Court held that the appeals court's standards were based on a misunderstanding of Ford that found a condemned prisoner's delusions irrelevant for the purposes of determining comprehension or awareness of his punishment. ${ }^{111}$ The Court instead looked to the Ford court's justification for capital punishment for guidance, specifically that the interests of retribution are only served if the offender at last recognizes the gravity of his crime. ${ }^{112}$ This recognition would affirm for the surviving family and friends of the victim, and the community as a whole that the prisoner is sufficiently culpable for his crimes and that the ultimate punishment is justified. ${ }^{113}$ Thus, a prisoner who did not fully appreciate the reason for his punishment, and thus the severity of his crime, would call this motive for retribution into question. ${ }^{114}$

104. See id. at 954-56.

105. Id. at 954.

106. Id. at $954-55$.

107. Id. at 955 .

108. The Court based its test around its interpretation of Justice Powell's concurrence in Ford, as the main opinion in the case was a plurality opinion, and Powell's concurrence had the narrower holding. See Ford v. Wainwright, 477 U.S. 399, 420-27 (1986) (Powell, J., concurring).

109. Panetti, 551 U.S. at 956.

110. Id.

111. Id. at $956-58$.

112. Id. at $958-59$.

113. Id.

114. Id. 
The Court found no support in Ford or the common law for the idea that a prisoner could be denied the ability to demonstrate incompetence merely because he could identify the stated reason for his execution. ${ }^{115}$ Instead, the Court held that Panetti's stated delusions were so severe as to render his ability to comprehend the meaning and purpose of his punishment doubtful. ${ }^{116}$ Thus, the Ford test for competency must include an evaluation of the petitioner's mental state with regard to any delusional beliefs he or she may have. ${ }^{117}$ Although the Court rejected the appeals court's standard, it did not impose a specific rule to govern all competency determinations. ${ }^{118}$ It instead preferred to leave questions of that complexity unaddressed until the lower courts fully addressed the nature and severity of Panetti's mental problems in a more definite manner and in light of all expert evidence. ${ }^{119}$ The Court reversed the appeals court's judgment and remanded Panetti's case for further proceedings consistent with its opinion. ${ }^{120}$

In Kennedy ${ }^{121}$ the Court considered the proportionality precedents established in Roper ${ }^{122}$ and Atkins, ${ }^{123}$ whereby diminished responsibility prevented application of the death penalty for homicide cases. Such

115. Id. at 959. The Court additionally recognized that the concept of "rational understanding" was difficult to identify, and that one could argue many criminals will fail to understand why they are being punished for reasons other than mental illness, including extreme callousness towards human life and the severity of their crimes or a level of self-centeredness that would prevent them from ever taking full responsibility for their actions. The Court distinguished Panetti's case from these hypotheticals by specifying that the doubting of Panetti's competence is not founded in "a misanthropic personality or an amoral character," but a psychotic disorder. Id. at 960.

116. Id. at 960 .

117. See id. (explaining that a competency test after Ford cannot treat delusional beliefs as irrelevant).

118. Id. at $960-61$.

119. Id. at 961 .

120. Id. at 962 . Despite more than a thirty-year history of schizophrenia, the same trial judge found Panetti to be competent to be executed. His attorneys learned of his execution date from the newspapers because state officials said the law did not require them to provide his attorneys with notification. Editorial Board, Will Texas Kill an Insane Man?, N.Y. TIMES, Nov. 24, 2014, at A28. Hours before his scheduled execution in December 2014, the Fifth Circuit Court of Appeals granted a stay of execution. Panetti v. Stephens, No. 14-70037, 2014 WL 6779138 at *164 (5th Cir. Dec. 3, 2014) (per curiam). He remains on death row. See Johnathan Silver, Panetti Case Highlights Cracks in Texas Execution Law, TEXAS TRIBUNE (Oct. 20, 2015), http://www.texastribune.org/2015/10/20/panetti-case-highlights-possible-gap-execution-law/.

Such last minute stays of execution are not just the stuff of movie plots. The first inmate to be put to death after the botched execution in Oklahoma also received a Fifth Circuit Court of Appeals stay two hours before his execution based on evidence of an IQ below 70. See Manny Fernandez and John Schwartz, Appeals Court Grants Stay of Execution in Texas Based on Mental Disability Claim, N.Y. TimeS, May 14, 2014, at A14.

121. Kennedy v. Louisiana, 554 U.S. 407, 421 (2008).

122. Roper v. Simmons, 543 U. S. 551 (2005).

123. Atkins v. Virginia, 536 U.S. 304 (2002). 
sentences should only have been invoked for "a narrow category of the most serious crimes" and whose extreme culpability makes them "the most deserving of execution." 124 Kennedy reaffirmed that the proportionality question is based upon "whether the death penalty is disproportionate to the crime committed[, which] depends as well upon the standards elaborated by controlling precedents and by the Court's own understanding and interpretation of the Eighth Amendment's text, history, meaning, and purpose." 125

Nevertheless, the existence of objective indicia of consensus against making a crime punishable by death was acknowledged in the Eighth Amendment cases of Roper, Atkins, Coker, and Enmund. ${ }^{126}$ In each case, state statistics for imposing capital punishment were considered as indicia of consensus, which "weigh[ed] on the side of rejecting capital punishment for the crime." 127

The Court acknowledged that while thirty-seven jurisdictions impose the death penalty, only six of those jurisdictions authorized the death penalty for rape of a child. ${ }^{128}$ The Court further emphasized that while national consensus is not confined to tallying the number of states with applicable death penalty legislation, significantly, in 45 jurisdictions the petitioner could not be executed for the rape of a minor. ${ }^{129}$

Overall, the Court held that "evidence of a national consensus with respect to the death penalty for child rapists, as with respect to juveniles, mentally retarded and vicarious felony offenders, shows divided opinion but, on balance, an opinion against imposing capital punishment." 130

Despite the Court's acknowledgement that those who rape deserve serious punishment, it held that "in terms of moral depravity and of the injury to the person and to the public, it does not compare with murder, which does involve the unjustified taking of human life." ${ }^{131}$ As the penalty for the rape of a minor was not addressed in Coker, the Court

124. Roper, 543 U.S. at 568 (quoting Atkins, 536 U.S. at 319).

125. Kennedy, 554 U.S. at 421 (citing Enmund v. Florida, 458 U.S. 782, 797-801 (1982); Coker

v. Georgia, 433 U.S. 584, 597-600 (1977); Gregg v. Georgia, 428 U.S. 153, 182-83 (1976)).

126. Id.

127. Id. at 426 (quoting Enmund, 458 U.S. at 793).

128. Id.

129. Id.

130. Id.

131. Id. at 427-28 (quoting Coker v. Georgia, 433 U.S. 584, 598 (1977)). 
found "that there is no clear indication that state legislatures have misinterpreted Coker to hold that the death penalty for child rape is unconstitutional." 132 The State argued that there was a consistent direction of change in support of the death penalty for child rape, reflected by six states where child rape is a capital offense, along with the states that have proposed but not yet enacted applicable death penalty legislation. ${ }^{133}$

The Court rejected such an argument as "it is not our practice, nor is it sound, to find contemporary norms based upon state legislation that has been proposed but not yet enacted."134 Furthermore, as the change towards imposing capital punishment for rape of a minor is only evidenced by six new death penalty statutes, three enacted in the last two years, there "is not an indication of a trend or change in direction comparable to the one supported by data in Roper." 135

Justice Kennedy's opinion went on to note that execution statistics confirm social consensus against the death penalty for non-deadly child rape. ${ }^{136}$ The statistics show that, although nine states permitted capital punishment for rape for some length of time after the Court's 1972 decision in Furman ${ }^{137}$ Louisiana was the only state since 1964 that has sentenced an individual to death for the crime of child rape. ${ }^{138}$ Furthermore, no execution for any other non-homicide offense has been conducted since $1963 .{ }^{139}$ As such, the Court concluded that the statistics provided show "a national consensus against capital punishment for the crime of child rape." 140

Despite the opinion's detailed scrutiny of whether there was a "national consensus" in either direction, Justice Kennedy's opinion asserted that ultimately it was the Court's own judgment which should be brought to bear on the death penalty's constitutionality under the Eighth Amendment, not the consensus of the states. ${ }^{141}$ The Court noted

132. Id. at 431

133. Id.

134. Id.

135. Id. at 433 .

136. Id. at 433 .

137. Furman v. Georgia, 408 U.S. 238 (1972) (holding that the death penalty cannot be applied in a prejudiced manner)

138. Kennedy, 554 U.S. at 434 (citing State v. Davis, No. 262,971 (1st Jud. Dist., Caddo Parish La. 2007), vacated per curiam, 995 So.2d 1211 (La. 2008)).

139. Id.

140. Id.

141. Id. at 446 . 
the importance of confined implementation of the death penalty to ensure punishment is "exercised within the limits of civilized standards" 142 and structured so as to "prevent the penalty from being administered in an arbitrary and unpredictable fashion." 143 In Enmund, the Court decided that the death penalty for the crime of vicarious felony murder is disproportionate to the offense, ${ }^{144}$ while Coker held capital punishment to be "an excessive penalty for the rapist who, as such, does not take human life." "145 Thus, the Court found that it is not only the death penalty which is "unique in its severity and irrevocability," 146 but there is also a distinction between intentional first-degree murders on the one hand and non-homicide crimes against individual persons, including child rape, on the other: ${ }^{147}$

We have developed a foundational jurisprudence in the case of capital murder to guide the States and juries in imposing the death penalty. Starting with Gregg, we have spent more than 32 years articulating limiting factors that channel the jury's discretion to avoid the death penalty's arbitrary imposition in the case of capital murder. Though that practice remains sound, beginning the same process for crimes for which no one has been executed in more than 40 years would require experimentation in an area where a failed experiment would result in the execution of individuals undeserving of the death penalty. ${ }^{148}$

The Court held that the fact there are more reported incidents of child rape than first-degree murder ${ }^{149}$ and that the 36 States that permit the death penalty could sentence to death all persons convicted of raping a child less than 12 years of age, could not be reconciled with our evolving standards of decency and the necessity to constrain the use of the death penalty. ${ }^{150}$

The opinion concluded with its evaluation that the imposition of the death penalty for such crimes would serve no legitimate penological purpose. ${ }^{151}$ Gregg $^{152}$ instructed that capital punishment is excessive

142. Id. at 435 (quoting Trop v. Dulles, 356 U.S. 86, 99-100 (1958)).

143. Id. at 436 (quoting California v. Brown, 479 U.S. 538, 541 (1987)).

144. Enmund v. Florida, 458 U.S. 782 (1982).

145. Coker v. Georgia, 433 U.S. 584, 598 (1977) (plurality opinion).

146. Kennedy, 554 U.S. at 428 (quoting Coker, 433 U.S. at 598).

147. Id. at 438

148. Id. at $440-41$.

149. Id. at 438 .

150. Id. at 439 .

151. See id. at 441-46 (concluding that retribution and deterrence do not justify the harshness of the death penalty in this type of case).

152. Gregg v. Georgia, 428 U.S. 153 (1976). 
when it is grossly out of proportion to the crime or it does not fulfill the two distinct social purposes served by the death penalty: retribution and deterrence of capital crimes. ${ }^{153}$ Atkins ${ }^{154}$ noted that the goal of retribution reflects the interests of the victim and society in seeing that the offender is punished for the hurt he caused. ${ }^{155}$ In respect of Kennedy, the Court noted that it is not evident that the victim's hurt is lessened when the law permits the death of the perpetrator. ${ }^{156}$ Furthermore, "enlisting the child victim to assist it over the course of years in asking for capital punishment forces a moral choice on the child, who is not of mature age to make that choice." 157 Finally, the Court noted the problem of "unreliable, induced, and even imagined child testimony means there is a 'special risk of wrongful execution' in some child rape cases," which would not fulfill any retributive value. ${ }^{158}$

Rather than being a deterrent, the death penalty for non-deadly child rape may have the opposite effect by increasing the risk of nonreporting of offences. "One of the most commonly cited reasons for nondisclosure is fear of negative consequences for the perpetrator, a concern that has special force where the abuser is a family member." 159 In addition, a state that punishes child rape by death may remove an incentive for the rapist not to kill the victim. ${ }^{160}$

The Court dismissed any concerns that its approach intruded upon the consensus-making process, as the Eighth Amendment is first and foremost defined by "the evolving standards of decency that mark the progress of a maturing society." 161 Accordingly, the Court "becomes enmeshed in the process, part judge and part the maker of that which it judges," but that "the rule of evolving standards of decency with specific marks on the way to full progress and mature judgment means that resort to the penalty must be reserved for the worst of crimes and limited in its instances of application." 162

153. Id. at 182

154. Atkins v. Virginia, 536 U.S. 304 (2002).

155. Id. at 319 .

156. Kennedy, 554 U.S. at 442.

157. Id. at 443 .

158. Id. (quoting Atkins, 536 U.S. at 321).

159. Id. at 445 .

160. $I d$.

161. Id. at 446 (quoting Trop v. Dulles, 356 U.S. 86, 101 (1958) (plurality opinion)).

162. Id. at 446-47. 
What emerges from Panetti and even more forcefully from Kennedy v. Louisiana is the reassertion of the Court's primacy over state consensus in determining what constitutes cruel and unusual punishment. That this assertion of Court authority comes from Justice Kennedy, one of the current Justices most receptive to issues of state authority, takes the Eighth Amendment quite clearly outside of any explicit or implicit balancing of state and federal interests. In Panetti, the Court took jurisdiction of Panetti's second habeas petition despite having rejected his first, found that Texas' procedures for determining competency did not provide a "fair hearing" under Ford without even specifying what procedures such a fair hearing might require, and refused to defer to Texas' determination of competency. ${ }^{163}$

In Kennedy, after performing the obligatory assessment of national consensus, Justice Kennedy asserts that regardless of that determination, the death penalty was cruel and unusual punishment for the category of crime as disproportionate and served no legitimate purpose of criminal punishment. ${ }^{164}$ When Justice Kennedy points out that the Court has spent 32 years trying to individualize determinations of capital sentencing, resulting in "tension and imprecision," and an approach which "might" be sound with respect to capital murder, the tone is almost one of exasperation in refusing to take that approach where death of the victim has not occurred. ${ }^{165}$

On January 26, 2016, the Court decided in Montgomery v. Louisiana ${ }^{166}$ that Miller's ${ }^{167}$ prohibition of life without parole sentences for juveniles at the time of the crime applied retroactively as a substantive rule under Teague v. Lane. ${ }^{168}$ Montgomery, 17 years old when he killed a deputy sheriff then 69 , had spent "almost his entire life" in prison. ${ }^{69}$ The issue revolved around whether Miller's pronouncement that the penalty was inappropriate except for crimes that "reflect permanent incorrigibility" was therefore only a procedural limitation on state sentencing, or a substantive exclusion of a category of offenders. ${ }^{170}$ Reciting proportionality analysis and lack of penological purpose from $\mathrm{Mil}$ ler, Justice Kennedy characterized Miller as a substantive, categorical

163. Panetti v. Quarterman, 551 U.S. 930 (2007).

164. Kennedy, 554 U.S. at 421.

165. Id. at 440-41.

166. 136 S. Ct. 718 (2016).

167. Miller v. Alabama, 132 S. Ct. 2455 (2012).

168. Montgomery, 136 S. Ct.at 736.

169. Id. at 726 .

170. Id. at 734 . 
exclusion of a category of offenders based on status, as in Roper. ${ }^{171}$ Finding no possibility of a "valid" (that is, reliable) result for such offenders, the opinion added that "even the use of impeccable fact-finding procedures could not legitimate a verdict" where "the conduct being penalized is constitutionally immune from punishment." ${ }^{172}$

The full implication of Kennedy's opinion was certainly not lost on Justice Scalia:

This whole exercise, this whole distortion of Miller, is just a devious way of eliminating life without parole for juvenile offenders. The Court might have done that expressly (as we know, the Court can decree anything) but that would have been something of an embarrassment. After all, one of the justifications the Court gave for decreeing an end to the death penalty for murders (no matter how many) committed by a juvenile was that life without parole was a severe enough punishment. How could the majority - in an opinion written by the very author of Roper - now say that punishment is also unconstitutional? The Court expressly refused to say so in Miller. So the Court refuses again today, but merely makes imposition of that severe sanction a practical impossibility. And then, in Godfather fashion, the majority makes states legislatures an offer they can't refuse: Avoid all the utterly impossible nonsense we have prescribed by simply 'permitting juvenile homicide offenders to be consider for parole. Mission accomplished. ${ }^{173}$

This passage is Justice Scalia's way of saying, "Et tu, Justice Kennedy?" The reference to Justice Kennedy being the author of Roper harks back to Justice Scalia's prediction in his dissent to Roper as to where that opinion might necessarily lead, unless, presumably, kept in check by its author, Justice Kennedy:

Nor does the Court suggest a stopping point for its reasoning. If juries cannot make appropriate determinations in cases involving murderers under 18, in what other kind of cases will the Court find jurors deficient? We have already held that no jury may consider whether a mentally deficient defendant can receive the death penalty, irrespective of his crime. See Atkins, 536 U.S. at 321. Why not take other mitigating factors, such as consideration of childhood

171. Id. at 734-35.

172. Id. at 730 (quoting United States v. U.S. Coin \& Currency, 401 U.S. 715, 724 (1971)).

173. Id. at 744 (Scalia, J., dissenting) (emphasis added) (citations omitted). 
abuse or poverty, away from juries as well? Surely jurors "overpower[ed]" by "the brutality or cold-blooded nature" of a crime, ... could not adequately weigh these mitigating factors either. ${ }^{174}$

As one authority on death penalty jurisprudence has noted, the $A t$ kins-Roper unreliability factors provide the potential of an overall challenge to the death penalty, by calling into question "the Court's most fundamental post-Furman promise that reliability can be assured because jurors are able to give full individualized consideration to each defendant." 175

\section{THE INEVITABILITY OF GLOBAL REALISM IN SUPREME COURT JURISPRUDENCE}

A few months after Glossip v. Gross, Justice Breyer published The Court and the World: American Law and the New Global Realities. ${ }^{176}$ The premise of the book is that the Supreme Court cannot avoid international law and practices in reaching its decisions. ${ }^{177}$ It deserves emphasis that Justice Breyer is not re-visiting the issue of actual application of international law in U.S. law. ${ }^{178}$ That hot button topic (sparked in part by Justice Kennedy's citation of foreign and international sources in Lawrence v. Texas ${ }^{179}$ ) is separate and distinct from the global reality (which this author refers to as global realism) that cases will increasingly have international aspects and consequences, and refusing to consider the legal experiences of other states in addressing domestic legal issues abdicates judicial responsibility. For example, the brief for Amicus Curiae International Human Rights Law Group in support of a pre-Roper juvenile defendant in High v. Zant, ${ }^{180}$ argued in the alternative that international standards informed the standards of decency to be met under the Eighth Amendment, and that international law prohibiting the execution of juveniles was binding on the United States as part of our domestic law. ${ }^{181}$

174. Roper v. Simmons, 543 U.S. 551, 621 (Scalia, J., dissenting).

175. Sundby, supra note 14 , at 524-25.

176. STEPHEN BREYer, THE COURT AND THE WORLD: AMERICAN LAW AND THE NEW GLOBAL REALITIES (Knopf 2015).

177. Id. at 7 .

178. See generally id. at 4 .

179. 539 U.S. 558 (2003).

180. Standford v. Kentucky, 492 U.S. 361 (1989).

181. Brief for International Human Rights Law Group as Amicus Curiae Supporting Petitioners at 11, Standford, 492 U.S. 361 (No. 87-6026), 1988 WL 1026342. 
As this author noted in 2003 shortly before Roper was decided, "The Supreme Court cannot avoid the internationalization of domestic law, as the five prominent international law cases on its docket this past term demonstrate." 182 Justice Breyer suggests that the interaction of judges and lawyers from different countries may be more influential than if or how other countries' legal decisions are cited. ${ }^{183}$ In his book's introduction, Justice Breyer states unequivocally that he believes "it important for Americans to understand and to appropriately apply international and foreign law." 184 In a speech to the Appellate Judges Education Institute on November 12, 2015, he added that looking abroad to other similar institutions is necessary to "solve" major international problems such as the environment and security. ${ }^{185}$

Most nations have abolished the death penalty. Of the 193 members of the United Nations, 95 have formally eliminated it while 42 others have ceased using it in practice. ${ }^{186}$ Furthermore, in 2013 only 22 countries carried out an execution and only 8 executed more than 10 people. ${ }^{187}$ The nations included in the eight nations that regularly execute people are ones with which the United States does not typically try to align itself on human rights issues (China, Iran, Iraq, Saudi Arabia, Somalia, Sudan, Yemen). ${ }^{188}$ In 2013 no execution took place in Europe or the Americas outside of the United States. ${ }^{189}$

There has been continuing pressure in the international community to eradicate the death penalty. Beginning in 1989, the United Nations General Assembly adopted a protocol to the International Covenant on Civil and Political Rights that laid out steps to abolish the death

182. Linda Malone, From Breard to Atkins to Malvo: Legal Incompetency and Human Rights Norms on the Fringes of the Death Penalty, 13 WM. \& MARY BILL RTS. J. 363, 412 (2004) (citing Lori Fisler Damrosch \& Bernard H. Oxman, Agora: The United States Constitution and International Law: Editor's Introduction, 98 AM. J. INT'L L. 42, 42 n.3 (2004)). The five cases were Padilla v. Rumsfeld, 542 U.S. 426 (2004); Rasul v. Bush, 542 U.S. 466 (2004); Hamdi v. Rumsfeld, 542 U.S. 507 (2004); Sosa v. Alvarez-Machain, 542 U.S. 692 (2004); and Roper v. Simmons, 543 U.S. 551 (2005).

183. BREYER, supra note 176 , at 7.

184. Id.

185. Nicholas Datlowe, Breyer: Court Must Look Abroad to Solve National, International Problems, 84 U.S.L. WK. 685 (2015).

186. Glossip v. Gross, 135 S. Ct. 2726, 2775 (2015).

187. Id. at 2775-76.

188. Id. In 2010, the overwhelming majority of known executions took place in only five of these: China, Iran, North Korea, Yemen, and the United States. AmneSTY INTERNATIONAL, DEATH SENTENCES AND EXECUTIONS 201041 (2011).

189. Glossip, 135 S. Ct. at 2776. 
penalty. ${ }^{190}$ Since then, opposition has grown worldwide with the number of nations opposed to capital punishment doubling. ${ }^{191}$ In 2014, the General Assembly voted on a resolution by a vote of 117-37 (with 34 abstentions) that called for a global moratorium on capital punishment. ${ }^{192}$ This was the fifth time since 2007 that the General Assembly had voted on such a resolution, with opposition to the death penalty increasing over time. ${ }^{193}$ Just since 1989, 67 nations have abolished capital punishment. ${ }^{194}$

Opposition to capital punishment has existed in Europe for many years. In 1962, a report to the Council of Europe revealed that "[a]n impartial glance at the facts clearly shows the death penalty [was] regarded in Europe as an anachronism. ${ }^{195}$ By 1994, twenty countries had ratified the Sixth Protocol to the European Convention on Human Rights, which outlawed the death penalty in peacetime. ${ }^{196}$ Currently, all of Western Europe has abolished the death penalty. ${ }^{197}$

In light of capital punishment's rarity, the United States' continued use of it has led to collateral consequences in the international community due to potential violations of treaties to which the U.S. is a party. Under Article 36 of the Vienna Convention on Consular Relations (which the United States has ratified), local authorities are obligated to inform all detained foreigners "without delay" of their right to request consular notification of their detention and their right to demand an

190. Second Optional Protocol to the International Covenant on Civil and Political Rights, Aiming at Abolition of the Death Penalty, Dec. 15, 1989, 1642 U.N.T.S. 414; U.N.G.A. 69/186, U.N. Doc. A/RES/69/186 (Dec. 18, 2014).

191. Samuel Oakford, UN Vote Against Death Penalty Highlights Global Abolitionist Trendand Leaves the US Stranded, VICE NEWS (Dec. 19, 2014), https://news.vice.com/article/un-voteagainst-death-penalty-highlights-global-abolitionist-trend-and-leaves-the-us-stranded.

192. U.N. GAOR, 69th Sess., 73d plen. mtg. at 17-18, U.N. Doc. A/69/PV.73 (Dec. 18, 2014).

193. Oakford, supra note 191.

194. Death Penalty Information Center, Abolitionist and Retentionist Countries, http://www.deathpenaltyinfo.org/abolitionist-and-retentionist-countries.

195. Eur. Comm. On Crime Problems, The Death Penalty in European Countries, 55 (1962).

196. Eur. Consult. Ass., Report on the Abolition of Capital Punishment, Doc. No. 7154 (1994).

197. Am. CIVIL Liberties Union, The Case Against the Death Penalty, https://www.aclu.org/case-against-death-penalty. It should be noted that the United States has consistently refrained from binding and non-binding international condemnations of the death penalty, relying upon the "persistent objector" rule as nullifying any evolving customary international law prohibiting the death penalty from applying to the United States. Beyond the scope of this article is the issue of what effect the "persistent objector" rule has on customary international law, if such a rule even exists. See generally Joel P. Trachtman, Persistent Objectors, Cooperation, and the Utility of Customary International Law, 21 DUKE J. OF COMP. \& INT'L L. 221 (2010); Jonathan I. Charney, The Persistent Objector Rule and the Development of Customary International Law, 56 BRIT. Y.B OF INT’L L. 1 (1986). 
opportunity to speak with their consular representatives. ${ }^{198}$ In 2004 , local and state authorities failed to carry out this obligation by not informing 51 Mexican nationals of this right, ultimately leading to an executive order calling on the states to comply with an ICJ decision as a matter of "comity" from President Bush and a case brought by Texas before the Supreme Court to establish its legal right to proceed with executions. ${ }^{199}$ All 51 of these individuals were sentenced to death. ${ }^{200}$ The International Court of Justice held that the states were in violation of the treaty and should "review and reconsider" the cases, ${ }^{201}$ but Texas refused to honor this judgment and indicated its intention to execute 15 death row inmates. ${ }^{202}$ In Medellin v. Texas, Medellín being one of the 51 Mexicans in Avena, the Supreme Court held that the ICJ's decision was not self-executing and as such was not enforceable as domestic law. ${ }^{203}$ Justice Breyer wrote the dissent, finding that the treaty, and thus the judgment of the ICJ in Avena, was self-executing and enforceable against the states including Texas. ${ }^{204}$

The availability of the death penalty in the United States has led to difficulties in seeking extradition from countries without the death penalty, particularly in Western Europe. In 1986, the United States sought extradition of German national Jens Soering, an 18-year-old student at the University of Virginia charged with killing his girlfriend's parents, from the United Kingdom, which refused to do so unless there were assurances that the death penalty not be imposed or carried out. ${ }^{205}$ Soering filed a petition seeking to have the European Court of Human Rights declare that he could not be extradited to the U.S., as it would violate Article 3 of the European Convention on Human Rights prohibiting inhuman or degrading treatment. ${ }^{206}$ The Court agreed that extradition violated Article 3, due to a "real risk" of Soering being executed in Virginia despite the United States' assurances to the contrary and the "death row phenomenon" (essentially the conditions inherent

198. Vienna Convention on Consular Relations art. 36(b), Apr. 24, 1963, 21 U.S.T. 77, 596 U.N.T.S. 261.

199. AM. CIVIL LIBERTIES UNION, supra note 197.

200. Id.

201. Case Concerning Avena and other Mexican Nationals, (Mex. v. U.S.), Judgment, 2004

I.C.J. Rep. 128, II 106 (Mar. 31). See generally, Malone supra note 182, at 407-09.

202. AM. CIVIL LIBERTIES UNION, supra note 197.

203. 552 U.S. 491, 506 (2008).

204. Id. at 538-39 (Breyer, J., dissenting).

205. Soering v. United Kingdom, 11 Eur. Ct. H.R. 439, 444 (1989).

206. Id. at 463 . 
in being on death row). ${ }^{207}$ The result is that the U.S. must seek assurances from the state that the death penalty will not be imposed before seeking extradition, with the state making the decision whether to insist on the death penalty at the expense of no extradition, whatever interests the U.S. might have in obtaining extradition of any individual.

In addition, the United States has signed the United Nations Convention Against Torture and Other Cruel, Inhuman or Degrading Treatment or Punishment. ${ }^{208}$ Given the unequal administration of the death penalty in terms of race in the United States, it has been argued that the United States is in violation of this treaty. ${ }^{209}$ The Convention also prohibits the intentional imposition of physical or psychological abuse against people who are being detained. ${ }^{210}$ Given the long delays between entry of a death sentence and executions during which inmates on death row are kept in solitary confinement as well as the torment that the appeals process often causes, in which a prisoner might on multiple occasions have an execution date set only to have it delayed, it can be argued that the United States is imposing psychological abuse. ${ }^{211}$ In several cases the European Court of Human Rights found that prolonged solitary confinement is torture under Article 3 of the European Convention of Human Rights. ${ }^{212}$ Furthermore, execution by any means could be construed as physical abuse under international norms, since errors leading to prolonged deaths are not uncommon. ${ }^{213}$

It is not surprising that Justice Breyer would lead the way in referencing international laws and practices in calling for abolition of the

207. Id. at 478 .

208. United Nations Convention Against Torture and Other Cruel, Inhuman or Degrading Treatment or Punishment, Dec. 10, 1984, 1465 U.N.T.S. 85 [hereinafter United Nations Convention].

209. AM. CIVIL LiBERTIES UNION, supra note 197.

210. United Nations Convention art. 1-2, supra note 208, at 113-14.

211. Am. CiVIL LiBerties Union, supra note 197; see also Glossip v. Gross, 135 S. Ct. 2726, 2765 (2015).

212. European COURT OF Human Rights, Factsheet-Detention Conditions and Treatment of Prisoners, www.echr.coe.int/Documents/FS_Detention_conditions_ENG.pdf. A California district court held that California's death penalty review system was so subject to delays and arbitrariness that that system itself was a violation of the Eighth Amendment. Jones v. Chappell, 31 F. Supp. 1050, 1062-63 (C.D. Cal. 2014). A year later, the Ninth Circuit Court of Appeals reversed on the grounds that the issue was too novel to be raised on federal habeas review under Teague v. Lane. Jones v. Davis, 806 F.3d 538, 541 (9th Cir. 2015).

213. AM. CIVIL LIBERTIES UNION, supra note 197. It may also be that the only way in which any lethal injection is administered may cause unnecessary pain and suffering. See Bucklew v. Lombardi, 565 Fed. App'x 562, 564-65 (8th Cir. 2014) vacated on reh'g en banc (staying an execution due to unrebutted medical evidence demonstrating a sufficient likelihood of unnecessary pain and suffering due to his vascular illness). 
death penalty. Financial records have revealed that he was the most well-traveled Justice internationally in 2013 and 2014, ${ }^{214}$ and in 2013 he was inducted into France's Académie des Sciences Morales et Politiques. ${ }^{215}$ What is overlooked is how the current Justices exemplify the global realities themselves in various ways, traveling internationally on a regular basis, having immigrant parents, studying abroad and teaching abroad. Indeed, as noted earlier, the impetus for Glossip v. Gross was the refusal of foreign companies to provide sodium thiopental or pentobarbital for executions in the United States. ${ }^{216}$

\section{MAKING THE CASE FOR SUPREME COURT ABOLITION OF THE DEATH PENALTY, SOONER RATHER THAN LATER}

Justice Ginsburg joined Justice Breyer in his dissent in Glossip v. Gross. It would be easy to include her vote against the death penalty and move on as being simply one more vote, but the significance of her joining in the dissent has broader implications for the decisions of the remaining members of the Court. Justice Ginsburg is not one to call for such a bold transition lightly. Despite her pop culture characterization as the "Notorious RBG" in part for her staunch advocacy of women's rights, ${ }^{217}$ she is a cautious, incremental advocate. In an editorial by Irin Carmon, she is quoted as advising young women, "My advice is fight for the things that you care about.... Fair enough - banal enough really .... But do it in a way that will lead others to join you." ${ }^{218}$ The editorial goes on to quote an ACLU colleague in her confirmation hearing: "'Present the court with the next logical step,' she urged us, and then the next and then the next. 'Don't ask them to go too fast, or you'll lose what you might have won."' ${ }^{219}$

Abolishing the death penalty, then, is the next logical step for the Court. Just a few weeks after Glossip, Justice Ginsburg spoke about it and other prominent cases from the term to an audience of Duke alumni and students at the D.C. Summer Institute on Law and Policy. ${ }^{220}$

214. Bill Mears, Justices' Finances Show Overseas Travel, Book Royalties, Gifts, CNN, (June 20, 2012) http://www.cnn.com/2012/06/20/us/scotus-justices-finances.

215. Adam Liptak, Breyer Sees Value in a Global View of Law, N.Y. TIMES, Sept. 13, 2015, at A20.

216. Glossip v. Gross, 135 S. Ct. 2726, 2733-34 (2015).

217. See generally IRIN CARMON \& SHANA KNIZHNIK, NOTORIOUS RBG: THE LIFE AND TIMES OF RUTH BADER GINSBURG (Dey Street Books 2015).

218. Irin Carmon, Justice Ginsburg's Cautious Radicalism, N.Y. TIMES, Oct. 25, 2015, at SR3.

219. Id.

220. Justice Ginsburg Discusses Ruling and Groundbreaking Advocacy, 34 DUKE L. MAG. 6, (2015) https://law.duke.edu/news/pdf/lawmagfall15.pdf. 
When asked why she and Justice Breyer had called for a review of the death penalty's constitutionality, she said: "Justice Breyer was speaking on the basis of his experience for 21 years, what he had seen in the Court's effort to create a capital punishment that could be administered with an even hand, and he concluded for reasons that he set out at length that it couldn't be achieved...."221

And so did she. Thus, two of the Justices with the most experience on the Court (only Justice Kennedy having more) have concluded that the death penalty is a failed experiment under Gregg. ${ }^{222}$ In that same conversation, Justice Ginsburg went on to emphasize her admiration for how Justice Thurgood Marshall as a civil rights advocate and stepby-incremental-step chipped away at racially discriminatory provisions until none could be left standing. She acknowledged keeping in her office Justice Marshall's volume of the opinions he had written which had not been accepted by a majority of the Court. ${ }^{223}$ Her vote in Glossip cannot be dismissed, on or off the Court, as a "liberal" vote. The significance of her vote also would not be lost on Justices Sotomayor and Kagan.

Again, it would be simplistic to count the votes of these latter two Justices as potential "liberal" votes against the death penalty. Indeed, they dissented separately from Justice Breyer in Glossip, but no less rigorously in their analysis. Finding that the Court's determination that midazolam poses on objectively intolerable risk of severe pain is "factually wrong," 224 these dissenters (also joined by Justices Breyer and Ginsburg) reserved their most forceful objection to the majority's interpretation of the plurality opinion in Baze v. Rees ${ }^{225}$ :

"By protecting even those convicted of heinous crimes, the Eighth Amendment reaffirms the duty of the government to respect the dignity of all persons." Roper v. Simmons, 543 U.S. 551 ... (2005). Today, however, the Court absolves the State of Oklahoma of this duty. It does so by misconstruing and ignoring the record evidence

221. Id. at 7

222. Gregg v. Georgia, 428 U.S. 153 (1976).

223. Justice Ruth Bader Ginsburg, Address at the Duke D.C. Summer Institute on Law and Policy (July 29, 2015).

224. Glossip v. Gross, 135 S. Ct. 2726, 2792 (2015). The use of midazolam gathered public attention in what is generally characterized as the botched execution of Clayton Lockett in Oklahoma in 2014. During the execution he gasped and writhed on the gurney, a vein collapsed, and he suffered a heart attack. It was reported that he grimaced and tensed his body several times before the execution was shielded from the press. After being declared unconscious, he spoke inaudibly twice and the said the word "man." See Blow, supra note 19.

225. 553 U.S 35 (2008). 
regarding the constitutional insufficiency of midazolam as a sedative in a three-drug lethal injection cocktail, and by imposing a wholly unprecedented obligation on the condemned inmate to identify an available means for his or her own execution. The contortions necessary to save this particular lethal injection protocol are not worth the price. ${ }^{226}$

The recent so-called "liberal" term of the Court has been attributed to splintering opinions of Justices Scalia, Thomas, Kennedy, and Alito even with agreed outcomes and the leadership of Justice Ginsburg. ${ }^{227}$ Justice Kennedy voted with the liberals (Breyer, Ginsburg, Kagan, and Sotomayor) eight times and the other Justices five times (compared to leaning to the right two-thirds of the time in previous terms) in the thirteen cases this past term decided by a five to four vote. ${ }^{228}$

Close scrutiny of the recent Supreme Court decisions on the death penalty and the assignment of those opinions reveals another significant factor for future death penalty jurisprudence. Since 1989, Justice Kennedy has written all of the majority opinions limiting the death penalty except for two decisions, Brumfield ${ }^{229}$ and Miller $^{230}$, as noted above. ${ }^{231}$ Justice Kennedy, as senior Justice in those majorities, assigned those opinions to the most junior Justices who wrote opinions accepted by all of the majority. In Miller, Justice Breyer wrote a short concurring opinion, which begins with, "I join the Court's opinion in full." ${ }^{232}$ In Glossip, Chief Justice Roberts assigned the majority opinion not to Scalia, Thomas or even Kennedy, but to Justice Alito. ${ }^{233}$ Justice Scalia joined the opinion in one phrase, and dedicated the rest of his opinion to addressing Justice Breyer's dissent. ${ }^{234}$ Justice Thomas, however, joined the majority opinion using a different test than that posed by Justice Alito, which rejected the reasoning of Baze by suggesting that the Eighth Amendment prohibits only methods of execution "deliberately designed to inflict pain," citing his concurrence in the Baze judgment only. ${ }^{235}$ The remainder of his opinion (and part of Justice Scalia's)

226. Glossip, 135 S. Ct. at 2797 (Sotomayor, J., dissenting).

227. Adam Liptak, Right Divided, Disciplined Left Steered Justices, N.Y. TimES, July 1, 2015, at A1 (quoting from an interview of Justice Ginsburg who stated, "We have made a concerted effort to speak with one voice in important cases ....").

228. Id.

229. Brumfield v. Cain, 135 S. Ct. 2269 (2015).

230. Miller v. Alabama, 135 S. Ct. 2455 (2012).

231. See supra notes 76-95 and accompanying text.

232. Miller, at 2475.

233. Glossip v. Gross, 135 S. Ct. 2726, 2731 (2015).

234. Id. at 2746 (Scalia, J., concurring).

235. Id. at 2750 (Thomas, J., concurring). 
attacking the empirical evidence employed by Justice Breyer, echoes, as John Donohue points out in this issue, the Justice Stevens/Justice Scalia debate over the relevance of empirical data in Baze. ${ }^{236}$

Justice Kennedy is notably silent beyond joining in the opinion. On a normative level, the majority opinion offers two reasons for affirming the Court of Appeals decision denying the prisoners' application for a preliminary injunction against execution:

First, the prisoners failed to identify a known and available alternative method of execution that entails a lesser risk of pain, a requirement all Eighth Amendment method-of-execution claims. See Baze v. Rees, 553 U.S. 35, 61 (2008) (plurality opinion). Second, the District Court did not commit clear error when it found that the prisoners failed to establish that Oklahoma's use of a massive dose of midazolam in its execution protocol entails a substantial risk of severe pain. ${ }^{237}$

Nothing in Justice Kennedy's joinder in this opinion poses any analytical inconsistency, much less barrier, to his joining in an opinion that the death penalty violates the Eighth Amendment. Nor is it necessary to overrule Baze to find the death penalty categorically violates the Amendment. To obtain any preliminary injunction, the petitioners must establish a likelihood of success on the merits. ${ }^{238}$ The plurality opinion in Baze provided so little guidance as to the constitutional limits on methods of execution that no outcome on the merits might be deemed "likely." With respect to this specific method of execution, the district court did not commit clear error in its factual determination that the evidence failed to establish that the protocol entailed a substantial risk of severe pain according to the majority. ${ }^{239}$ Procedurally, Glossip on its facts failed to meet the standard for a preliminary injunction or to provide the necessary evidentiary basis as to pain inflicted by the protocol. ${ }^{240}$

The only significant normative precedent of the Glossip majority opinion is the imposition of a requirement on prisoners to identify a

236. Id. at 2751-53; Id. at 2747-48 (Scalia, J., concurring). See also John Donohue, Empirical Analysis and the Fate of Capital Punishment, 11 DUKE J. CONST. L \& PUB. POL'Y STARTPAGE\#, PINCITE (2016).

237. Glossip, 135 S. Ct. at 2731 (majority opinion).

238. Id. at 2736-37 (citing Winter v. NRDC, 555 U.S. 7, 20 (2008))

239. Baze v. Rees, 553 U.S. 35, 41 (2008).

240. Glossip, 135 S. Ct. at 2792 (Sotomayor, J., dissenting). 
"known and available alternative method of execution." 241 It is this purported requirement, supported only by a "see" citation to the plurality opinion in Baze, ${ }^{242}$ that triggered the dissenting opinion of Justice Sotomayor, joined by Justices Kagan, Breyer, and Ginsburg and which necessitated the footnote in Justice Alito's opinion defining the holding in Baze (given that only Justices Kennedy and Alito joined in the reasoning of the Chief Justice's opinion in Baze). ${ }^{243}$

Beyond procedural hurdles and searching for some common thread in a fractured Court decision, Baze is a very slender reed on which to find a method of execution (which Justice Sotomayor twice calls "the chemical equivalent of burning alive" 244 ) or the death penalty, to be sufficiently humane under the Eighth Amendment. ${ }^{245}$ Justices Alito, Scalia, and Thomas dismiss years of credible empirical evidence on the discriminatory and otherwise arbitrary imposition of the death penalty, yet require of prisoner-petitioners in Glossip to advance clear evidence medically and scientifically that a method of execution imposes a severe level of pain. ${ }^{246}$

\section{Why ABolition By the SUPREME COURT AND Why NOW}

Justice Breyer's invitation for a categorical death penalty challenge before the Court has ignited a discussion as to when and how such a challenge might be brought. ${ }^{247}$ It has been suggested that veteran litigators favor an incremental, more cautious strategy, challenging the penalty's implementation in the courts (for example, seeking a categorical exclusion for execution of the mentally ill) and seeking state-by-

241. Id. at 2731 (majority opinion).

242. Id.

243. See id. at 2738 n.2 ("Justice Sotomayor's dissent ... inexplicably refuses to recognize that the Chief Justice's opinion in Baze sets out the holding of the case. In Baze, the opinion of the Chief Justice was joined by two other Justices. Justices Scalia and Thomas took the broader position that a method of execution is consistent with the Eighth Amendment unless it is deliberately designed to inflict pain. Thus, as explained in Marks $v$. United States, . . the Chief Justice's opinion sets out the holding of the case. It is for this reason that petitioners base their argument on the rule set out in that opinion." (citations omitted)).

The analysis of the dissent that Baze did not hold as Justice Scalia contends in the case itself or under Marks is at Glossip, 135 S. Ct. at 2793-94 (Sotomayor, J., dissenting).

244. Id. at 2793, 2795 (Sotomayor, J., dissenting).

245. Id. at. 2796.

246. Id. at 2728 (majority opinion); id. at 2747-48 (Scalia, J., concurring); id. at 2751-52 (Thomas, J., concurring).

247. See Adam Liptak, Death Penalty Foes Torn on When to Press Case, N.Y. TIMES, Nov. 4, 2015, at A1. 
state legislation, with younger lawyers seeking an immediate nationwide decision from the Court. ${ }^{248}$ Even assuming that is the case, there is a veteran litigator on the Court known for her incremental and cautious approach who has now gone on record for a challenge to be brought now. ${ }^{249}$

There are cases in the pipeline that can be utilized. ${ }^{250}$ It would not be difficult to find a mentally ill petitioner to challenge both execution of the mentally ill and the death penalty generally as cruel and unusual punishment. ${ }^{251}$ The likelihood of every death penalty case to come before the Court containing a general Eighth Amendment challenge if possible procedurally is a virtual professional prerequisite after Breyer's and Ginsburg's invitation to counsel to do so. On May 31, 2016, the Court denied certiorari in Tucker v. Louisiana, in which the defendant's counsel echoed Breyer's dissent. Tucker barely qualified for the death penalty imposed as he was 18 at the time of the killing and had an I.Q. of 74. Moreover, he was sentenced in Caddo Parish, which imposes more death sentences per capita than any other parish or county in the United States. ${ }^{252}$ Justices Breyer and Ginsburg dissented from the denial of certiorari, with Breyer in his dissent suggesting that the sentence was the arbitrary result of the county in which he committed the crime. ${ }^{253}$ The denial of certiorari itself was in keeping with the Court's avoidance of deciding the remaining high profile in the Court's term during the vacancy, and hardly surprising or inauspicious

248. Id.

249. See Glossip, 135 S. Ct. at 2755.

250. See e.g., Ex parte Murphy, No. WR-38,198-03, 2014 WL 6462841 (Tex. Crim. App. Nov. 19, 2014), cert. denied sub nom. Murphy v. Texas, 135 S. Ct. 2350 (May 26, 2015). Julius Murphy was sentenced to death for robbing and killing a stranded motorist in Texas. One of his lawyers is Neal Katyal, an experienced Supreme Court litigator and former Acting Solicitor General of the United States (and former law clerk to Justice Breyer). The brief to the Texas Court of Criminal Appeals included a general challenge to the death penalty. Application for Writ of Habeas Corpus at 43, Ex parte Murphy, No. WR-38,198-03, 2014 WL 6462841 (Tex. Crim. App. Nov. 19, 2014), https://drive.google.com/file/d/0B1Lfr8Iqz_7a2tkSW1VSjI4ekE/view. See also Liptak, supra note 247 . His petition for certiorari on procedural issues related to intellectual disability was denied on May 26, 2015. Murphy v. Texas, 135 S. Ct. 2350 (May 26, 2015).

The attorneys for Dylann Roof, the man accused of killing nine black church members in a Charleston, South Carolina church in 2015, have filed a motion challenging the death penalty after federal prosecutors declined Roof's offer to serve life without parole, citing Justice Breyer's dissent in Glossip.

251. See id.

252. See generally Adam Liptak, Supreme Court Rules in Capital Cases, overturning an Arizona Death Sentence, N.Y. TIMES, June 1, 2016, at A10.

253. Tucker v. Louisiana, No. 15-947 (May 31, 2016), 578 U.S. (2016). 
for similar challenges for that reason. It is significant, however, that Justice Breyer chose to renew his position in Glossip in a written dissent from a denial of certiorari.

There is another casualty of the death penalty, and that is the public perception of the integrity of the Supreme Court. Linda Greenhouse, Pulitzer Prize winning journalist for her coverage of the Supreme Court, exposed the "death trap" of the Supreme Court in connection to Glossip and other cases and its impact on public perception of the objectivity of the Court. ${ }^{254}$ Furthermore, Adam Liptak, the Supreme Court respondent for the New York Times, discussed a death row petitioner, Charles F. Warner, who brought a challenge to Oklahoma's lethal-injection protocol, and sought a stay of his execution. ${ }^{255}$ Over four dissenting votes, the stay was denied and Oklahoma executed the prisoner within hours. ${ }^{256} \mathrm{~A}$ week later, three identically situated prisoners brought Glossip, and were granted a stay of execution through a stay of the lower court decision when the Court took their petition. ${ }^{257}$ It takes five Justices to grant a stay, but only four to hear a case, a lifeand-death procedural difference. ${ }^{258}$ It is not the only instance in which a stay of execution has come and gone without explanation. ${ }^{259}$ Greenhouse's final paragraph is prescient:

In 2008, two years before he retired, Justice John Paul Stevens renounced the death penalty. His nuanced opinion in Baze v. Rees rewards rereading. No current justice has taken up the call. I'm not so naïve as to predict that a majority of the Supreme Court will declare the death penalty unconstitutional anytime soon. But the voice of even one member of the court could set a clarifying marker to which others would have to respond. And it just might over time point the way to freeing the court-and the rest of us-from the machinery of death. ${ }^{260}$

Two months later, Justice Breyer would issue his dissent in Glossip. One year later, this author is hopeful enough (or naïve enough to those who disagree) that a challenge can be mounted now before many more

254. Linda Greenhouse, The Supreme Court's Death Trap, N.Y. TIMES, April 1, 2015, at A23.

255. Adam Liptak, Justices to Hear Case Over Drugs Used in Executions, N.Y. TIMES, Jan. 23, 2015, at A1.

256. Id.; see also Lance Rogers, Oklahoma Executes Man Using New Protocol after Justices Deny Eleventh-Hour Stay, 83 U.S.L.W. 1048 (Jan. 20, 2015).

257. Greenhouse, supra note 254.

258. Id.

259. Id.; see also William Baude, The Supreme Court's Secret Decisions, N.Y. TIMES, Feb. 3, 2015 , at A23.

260. Greenhouse, supra note 254. 
executions occur.

As this article was being presented, Justice Scalia died, leaving a vacancy on the Court which immediately flared into partisan politics. ${ }^{261}$ The thrust of this article was that a Court with Justice Scalia might already be prepared to find the death penalty unconstitutional. Whatever the political bent, perceived or actual, of a Supreme Court nominee, it would be unusual for that inclination to be coupled with the level of skepticism toward empirical evidence of Justices Scalia and Thomas. This conclusion of possible if not probable abolition remains the same even if a newly elected Republican president were to appoint a Scaliaequivalent justice to the Court. The vacancy on the Court could be an opportunity to restore the image of thoughtful justice to the Court, an opportunity that may already have been lost but not irretrievably. No single issue, pro or con, should be a political litmus test for appointment to the Court if the Court is to rise above the partisan polarization of the other branches. Having left the New York Times after three decades to join academia, Linda Greenhouse is open about the need for "resetting the post-Scalia Court." 262 As Justice Scalia's opinions became more vitriolic the Court seemed to reflect the harsh and often disgraceful rhetoric of the Presidential primaries. In her editorial, Greenhouse refers to an article by law Professor Neal Devins and political science professor Lawrence Baum, that explores how party polarization may have infected the Court's objectivity and at the least damaged the public's perception of its objectivity. ${ }^{263}$ Hopefully, political liberals and conservatives will recognize this need, at some point in the future acknowledge that it is not unprecedented for a President to appoint a Supreme Court Justice in an election year, and reinstate judicial thoughtfulness and integrity as the goal, not "stacking" the Court.

261. Russell Berman, A Death that Reshapes U.S. Politics, ThE ATlantic (Feb. 13, 2016), http:/www.theatlantic.com/politics/archive/2016/02/antonin-scalia-death-politics-senate-2016campaign-obama/462738.

262. Linda Greenhouse, Resetting the Post-Scalia Supreme Court, N.Y. TIMES, Feb. 18, 2016, at A25. Conversely, if party politics continues to predominate, the urgency of a challenge to the death penalty to this Court, even with a new appointee, is preferable to having such a critical issue determined by a post-election Court perceived as either strongly "liberal" or "conservative" based on a number of appointments being made due to retirements of senior justices in a single Presidential term.

263. See id. (referring to forthcoming law review article, Neal Devins \& Lawrence Baum, Split Definitive: How Party Polarization Turned the Supreme Court into a Partisan Court (Wm. \& Mary L. School Legal Stud. Res. Paper Series, Working Paper No. 09-276, Mar. 16, 2016) http://papers.ssrn.com/sol3/papers.cfm?abstract_id=2432111). 
The final words are those of Justice Breyer:

In interpreting these open (constitutional) phrases, a judge may in part have to face the fact that he cannot jump out of his own skin, he cannot escape his own background, and he is guided by a highly general jurisprudential philosophy that he will likely have accepted over the course of many professional years. I went to public schools in San Francisco; I grew up during the 1950s; I am inevitably the lawyer that I am. That means in respect to views about the nature of the Constitution or of law, their relation to the people of the United States, and the way in which law affects people, I cannot escape my own general views. Law is not computer science, and those views matter. That is why it is a good thing, in a country as diverse as ours, with well over three hundred million people, that different judges have different general jurisprudential views. I should add that judges serve long terms, but over time different presidents will appoint different judges with different highly general jurisprudential views. The Court can change its nature very slowly over time. And in a few cases it can reflect, in a highly abstract general sense, the nature of the country. ${ }^{264}$

The present political fracas over whether Judge Garland ${ }^{265}$ is even going to get a confirmation hearing before the election admittedly does not bode well for Congress to demonstrate a renewed respect for a Supreme Court above the political fray. "Liberal" or "conservative" labels do not reflect in any meaningful way on evaluating Judge Garland's record or on the actual precedent for Senate hearings and action on Supreme Court nominees during an election year (most notably and recently Justice Kennedy himself). The standard argument against having the Court decide cases involving substantial change in a societal norm - that such decisions are best left to the state legislatures as expressing the will of the people-simply has no applicability in the context of a death penalty with all of its societal and human costs imposed in only a handful of counties in a handful of states, which might not come around to the general state consensus in practice for any number of years. The will of the people in such circumstances is held captive to a localized veto which does not reflect a national consensus but frustrates it, at tremendous expense in human life and public perception of

264. BREYER, supra note 176 , at 277-78.

265. See supra note 23 and accompanying text. Judge Garland is best known as a centrist jurist with a "meticulous work ethic" and who favors an "adherence to legal principles" rather than a strong ideological bent. Michael D. Shear et al., Obama Chooses Merrick Garland for Supreme Court, N.Y. TIMES (March 16, 2016), http://www.nytimes.com/2016/03/17/us/politics/obama-supreme-court-nominee.html. 
the integrity of the legal system. The empirical evidence that the death penalty is imposed in only a few states, ${ }^{266}$ and in only a few counties of those states, ${ }^{267}$ demonstrates that the national consensus has shifted ${ }^{268}$ even should such methodology predominate over the prevailing methodology, as exemplified by the Kennedy case, in which the Court determines what punishment reflects "evolving standards of decency."269

266. See John Donohue, Empirical Analysis and the Fate of Capital Punishment, 11 DUKE J. CONST. L \& PUB. POL'Y 52 (2016); Frank Baumgartner, The Geographic Distribution of US Execution, 11 DUKE J. CONST. L \& PUB. POL'Y 1 (2016).

267. See, e.g., John H. Blume \& Lindsey S. Vann, Forty Years of Death: The Past, and Future of the Death Penalty in South Carolina (or Still Arbitrary after All These Years, 11 DUKE J. CONST. L \& PUB. POL'Y 183 (2016).

268. See, e.g., State v. Peeler, 318 Conn. _(2016) (reaffirming that Court's earlier opinion in State v. Santiago, 318 Conn. 1(2015), following legislative abolition of the death penalty). Santiago held that the death penalty violates the state constitutional provision against cruel and unusual punishment, applying retroactively prior to the legislative abolition. See also Erik Eckholm, Delaware Supreme Court Ruling Could Deal State's Death Penalty A Final Blow, N. Y. TIMES, Aug. 3, 2016, at A11.

269. Meanwhile, the Supreme Court continues to struggle with ongoing issues which exemplify how the death penalty fails to comply with "evolving standards of decency." On June 6, 2016, the Supreme Court granted certiorari for the upcoming terms concerning the impacts of race, intellectual disability, and incompetent counsel in the imposition of the death penalty. In one case the prosecutor and the defendant's own expert witness stated that black defendants were more likely to be dangerous than white defendants. In the other the Court agreed to hear the appeal of a defendant with an intellectual disability who has been on death row for 36 years. In its initial announcement the Court said it would hear both the appeal on the standard used for intellectual disability and also whether 36 years on death row itself constituted cruel and unusual punishment. Two hours later the Court issued a revised order limiting review to the disability standard. Adam Liptak, Supreme Court to Hear Death Penalty Cases, N.Y. TIMES, June 7, 2016, at A11. A chart of the categorical exclusions follows. 


\section{APPENDIX}

CATEGORICAL EXCLUSIONS FROM THE DEATH PENALTY

Gregg v. Georgia (1976) (ending the Furman v. Georgia morato rium)

Coker v. Georgia (1977) (rape of an adult)

Enmund v. Florida (1982) (felony-murder without sharing in the homicidal act or intent)

Atkins v. Virginia (2002) ("mentally retarded")

Roper v. Simmons (2005) (juveniles)*

Kennedy v. Louisiana (2008) (rape of child without intent to kill or resulting in death)

*Graham v. Florida (2010) (no life without parole for juveniles for non-homicidal offenses

Miller v. Alabama (2012) (no life without parole for juveniles for any offense)

Montgomery v. Louisiana (2016) (Miller v. Alabama retro active) 